\title{
EL RECURSO DE AMPARO CONTRA TRIBUNALES
}

\author{
POR \\ AURELIO GUAITA \\ Catedrático de la Universidad Autónoma de Madrid
}

\begin{abstract}
SUMARIO
1. Los tribunales ORdiNARIOS, PROTECTORES DE TODOS LOS DERECHOS, TAMBIÉN DE LOS FUNDAMENTALES.-2. El PRECEDENTE DE LA CONSTITUCIÓN REPUBLICANA. - 3. El aMPARO CONTRA JUECES EN LA LOTC.-4. EL ÓRGANO JUDICIAL: a) ¿Consejo general del poder judicial? b) y c) Jueces y tribunales. d) Procedimientos militares.-5. Los DEREchos vulnerados: a) Preceptos diversos. b) Artículo 24 de la Constitución.-6. IMPUTACIón DIRECTA E INMEDIATA AL JUEZ.-7. INVOCACIÓN DEL DERECHO VULNERADO.-8. QUE SE HAYAN AGOTADO TODOS LOS RECURSOS UTILIZABLES DENTRO DE LA VÍA JUDICIAL. -9. «ADDENDA》 DE ALCANCE.
\end{abstract}

\section{LOS TRIBUNALES ORDINARIOS, PROTECTORES DE TODOS LOS DERECHOS, TAMBIEN DE LOS FUNDAMENTALES}

Según el art. 117.3 de la Constitución, «el ejercicio de la potestad jurisdiccional en todo tipo de procesos... corresponde exclusivamente a los juzgados y tribunales determinados por las leyes...», y en aplicación concreta de ese principio general al caso de los derechos fundamentales y libertades públicas leemos en el art. 53.2 que «cualquier ciudadano podrá recabar la tutela de las libertades y derechos reconocidos en el art. 14 y la sección primera [arts. 15-29] del capítulo segundo ante los tribunales ordinarios por un procedimiento basado en los principios de preferencia y sumariedad y, en su caso, a través del recurso de amparo ante el Tribunal Constitucional. Este último recurso será aplicable a la objeción de conciencia reconocida en el artículo 30».

Es evidente que en ese contexto, «tribunales ordinarios» (y «jurisdicción ordinaria»: art. 53.3) no se reducen a los tribunales civiles ${ }^{1}$, sino que, al

${ }^{1}$ Que es lo que les parece conveniente y posible a Rubio Llorente y Aragón Reyes, que concretan más, residenciando el tema en los jueces de primera instancia: «La jurisdicción constitucional»; en el volumen colectivo dirigido por Predieri y García de Ente. rría, La Constitución española de 1978, estudio sistemático, 2." ed., Madrid, 1981, página 875. 
contrario, comprenden, sin excepción, todos los tribunales (y jueces) integrados en el Poder Judicial, incluso los de la jurisdicción militar (principio de unidad jurisdiccional: cfr. art. 117.5); es decir, tribunales ordinarios son todos, absolutamente todos (civiles, penales, contencioso-administrativos, laborales y militares), sin más excepción que el Tribunal Constitucional.

Así lo entendió la ley de 26 de diciembre de 1978 sobre protección jurisdiccional de los derechos fundamentales de la persona, que dedica sendas secciones a las garantías penal, contencioso-administrativa y civil ${ }^{2}$.

Pero aparte y además de esa diversidad de órdenes judiciales que integran la jurisdicción y los tribunales ordinarios, la Constitución y la ley de protección de estos derechos de 1978 enseñan bien claramente, acabamos de verlo, que la tutela y amparo originarios compete a aquellos mismos tribunales, a los integrados en el Poder Judicial, o sea, a los tribunales. Por supuesto, así lo proclama el art. 41.1 LOTC al proveer a la garantía de los derechos y libertades de que se trata: «su tutela general [está] encomendada a los Tribunales de Justicia»; y, claro está, lo mismo la jurisprudencia del Tribunal Constitucional (TC), empezando por su primera sentencia, de 26 de enero de 1981 ( $B O E$ de 24 de febrero): el recurso de amparo ante el TC sólo procede

«cuando las vías ordinarias de protección han resultado insatisfactorias»; «corresponde a los mismos [jueces y tribunales] la tutela general de tales libertades y derechos»: sentencia de 29 de enero de $1982, B O E$ de 26 de febrero; o el auto de 1 de julio de 1981: «el restablecimiento del derecho debe primariamente tratarse de conseguir ante los tribunales ordinarios».

a) Que se instrumente un proceso especial (o especialidades en los procesos ordinarios penal, civil, laboral...) para una eficaz protección de los derechos fundamentales ante la jurisdicción y tribunales ordinarios («un procedimiento basado en los principios de preferencia y sumariedad») es perfectamente comprensible dado el justificado énfasis que la Constitución pone en este asunto... y supuesto que los procesos ordinarios, con o sin reformas, no sean adecuados para esta tarea ${ }^{3}$.

2 Una proposición de ley publicada en el BOCG.CD, B-171, de 26 de febrero de 1982, agrega una cuarta sección dedicada a la garantía jurisdiccional social.

La ley en cuestión, provisional pero subsistente, se gestó simultáneamente con la Constitución; ahora bien: aunque está fechada un día antes que ésta, se publicó en el $B O E$ de 3 de enero de 1979, esto es, cuando la Constitución ya estaba en vigor (desde el 29 de diciembre de 1978), y la verdad es que nació inconstitucional, porque debió haber sido una ley orgánica (art. 81.1 Const.) y porque reducía la protección a unos cuantos derechos fundamentales, no la extendía a todos, que es lo que ya disponía el art. 53,2 de la Constitución; un decreto de 20 de febreto de 1979 amplió algo esa lista, peto tampoco llegó al techo exigido, que es lo que hizo la disposición transitoria 2.2 de la Ley Orgánica del Tribunal Constitucional de 3 de octubre de 1979 (LOTC), que extendió y extiende el ámbito de la ley citada «a todos los derechos y libertades a que se refiere el exprsado art. 53.2 Const.». Comentarios a la LOTC en Almagro Nosete, Justicia constitucional, Madrid, 1980.

3 «En realidad; con una adecuada estructuración de los procesos ordinarios, y muy especialmente del proceso administrativo, resultaría innecesaria la implantación de este proceso especial.» González Pérez, Derecbo procesal constitucional, Madrid, 1980, pág. 277. 
b) Que no satisfechas las pretensiones del interesado, cuando la real o supuesta lesión de sus derechos fundamentales se deba a «los poderes públicos» (arts. 9.1 y 53.1 Const. y 4.2 LOTC), proceda un proceso o recurso de amparo ante el $\mathrm{TC}^{4}$ es más discutible y discutido, pues una justicia (ordinaria) bien estructurada debe bastar para proteger todos los derechos, incluidos los fundamentales ${ }^{5}$.

c) En fin, que ese proceso o recurso de amparo ante el TC pueda utilizarse contra «los poderes públicos» in genere, contra todos o cualquiera, esto es, no sólo contra las Cortes y especialmente contra el Gobierno y las Administraciones públicas y los organismos análogos de las Comunidades autónomas, sino también contra los jueces y tribunales, esto ýa és cósa más recia y no sólo para los profanos en materias jurídicas. Y se comprende, pues jueces y tribunales han sido instituidos precisamente para proteger y amparar los derechos de todos, incluso los fundamentales, como acabamos de recordar: y el recurso de amparo contra sus decisiones y ante un organismo ajeno al Poder Judicial (como lo es el TC: sentencia de 31 de marzo de 1981, BOE de 14 de abril) supone, claro es, no sólo o no ya que el juez o tribunal no ha amparado, sino, más gravemente, que es reputado como autor del hecho u omisión contra el que pedimos amparo; supone que el autor del desafuero es precisamente quien debía ampararnos, lo que obliga al lesionado a buscar amparo fuera del Poder Judicial ${ }^{6}$.

${ }^{4}$ Conviene tener presente que, cuando la lesión de derechos fundamentales no se debe a los poderes públicos, no cabe recurso de amparo ante el TC, sino sólo el proceso especial penal, civil, laboral o penal militar. Por eso la disposición transitoria 2.2 LOTC dice, con razón, que «la vía judicial previa a la interposición del recurso de amparo será. la contencioso-administrativa ordinaria o la configurada en la sección 2." de la Ley 62/1978, de 26 de diciembre, sobre Protección Jurisdiccional de los Derechos Fundamentales», pues esa vía judicial previa al amparo constitucional sólo existe frente a la Administración, y es, naturalmente, el recurso contencioso-administrativo.

Pero cuando el asunto es entre particulares, se repite, no cabe llegar al amparo constitucional ni a la vía previa contencioso-administrativa. Tampoco «se impone» ésta, ni es posible, cuando el amparo se pide al TC frente a jueces o tribunales. Opina en contra Fairén, «Algunos problemas procesales que plantea la LOTC española», en la obra colectiva El Tribunal Constitucional, II, Madrid, 1981, pág. 1021 (en adelante El Trib. Const.); lo mismo sucede con Friginal para el tema concreto que cita del habeas corpus, «Aproximación a una tesis articuladora de los recursos de amparo y contencioso-administrativo», en ibíd., pág. 1141, y con Jiménez Hernández para actos de particulares en general, «El recurso de amparo constitucional respecto de resoluciones judiciales», en ibid., págs. 1326 . 1327. Pero se trata, sin duda, en esos tres y otros casos, de una distracción, que también tuve yo en un momento de urgencia.

${ }_{5}^{5}$ « $\mathrm{Si}$ actualmente se establece una jurisdicción contencioso-administrativa sin restricciones basada en la cláusula general, ¿qué queda para un recurso de amparo que ha de ser tramitado y resuelto nada menos que por el Tribunal Constitucional?». Garrido Falla, Comentarios a la Constitución, Madrid, 1980, pág. 587.

6 «Supuesto delicado, puesto que enfrenta la actuación de los jueces ordinarios con las facultades de los jueces constitucionales...; empero, la inclusión [del supuesto en el texto constitucional] no debe considerarse ociosa.» Garrido Falla, ob. cit., págs $589-590$ y 1697; pero en la siguiente página 1698 habla del recurso de amparo ante el TC como de «la equivocada vía de revisar al Tribunal Supremo».

No son menos contundentes y expresivas estas palabras de Pera Verdaguer, quien, después de aludir a las «legislaciones que encomiendan precisamente al más alto órgano judicial estos temas», al Tribunal Supremo, se refiere amargamente (?) a la pretensión «reductora de esos mismos órganos judiciales..., a la condición de potenciales violadores 


\section{EL PRECEDENTE DE LA CONSTITUCION REPUBLICANA}

En efecto, el recurso de amparo de la Constitución vigente de 1978 no ha surgido ex nibilo, tiene su antecedente en la de 1931, y no sólo en general, la institución en sí, sino también para lo que ahora interesa, para el tema propio de esta colaboración, el recurso de amparo frente o contra «autoridades» u «órganos» judiciales ?.

Para nuestro objeto basta recordar de la legislación republicana: a) que «el recurso de amparo de garantías individuales [sólo procedía] cuando hubiera sido ineficaz la reclamación ante otras autoridades», ante la «autoridad competente... [que era] el superior jerárquico inmediato del agente o autoridad que haya causado el agravio»; la reclamación previa al recurso de amparo había de formularse en cinco días, y el superior ad quem debía resolverla en otros cinco, «transcurridos los cuales sin resolución se considerará denegada»; superior jerárquico era el «que por motivos de poder y subordinación en la jerarquía administrativa resulte con este carácter, o al que en organizaciones de otro orden corresponda el conocimiento de los recursos contra las decisiones de determinada autoridad»; $b$ ) presupuesto del recurso de amparo era «que exista acto concreto de autoridades gubernativa, judicial o de cualquier otro orden que... haya infringido...», acto «que deberá tener carácter de firme por haberse desestimado las acciones y los recursos interpuestos contra el mismo ante las autoridades e instancias competentes»; c) frente al amplio y minucioso art. 24 de la Constitución actual («derecho a la justicia», en general), el 28 de la de 1931 era mucho más breve y abstracto; y d) en la legislación republicana del recurso de amparo no había ningún precepto específico para el supuesto de que el causante del agravio fuese una autoridad judicial.

De los treinta y cinco o cuarenta recursos de amparo resueltos ${ }^{8}$ en 1934-37, no hay ni uno contra «autoridades judiciales»: todos fueron contra autoridades administrativas; la mayor parte en materia de orden público; y fueron estimados dos tercios del total de recursos de amparo.

de derechos fundamentales y libertades públicas». «Violación de derechos y libertades por órganos judiciales, en El Trib. Const., III, págs. 2116-2117.

7 Arts. 45.1 de la Ley Orgánica del Tribunal de Garantías Constitucionales de 14 de junio de 1933 y 44.1 LOTC, respectivamente.

La Constitución de 1931 aludía al recurso de amparo en los arts. 105 y 121.b); la Ley de 1933 lo regulaba en los atts. $44-53$ y en la disposición transitoria segunda, y su Reglamento de 6 de abril de 1935 en los arts. 95-101. El anterior de 8 de diciembre de 1933 no contenía normas procesales.

- $\mathrm{O}$ al menos de los que se tiene constancia documental: cfr. J. L. García Ruiz, El recurso de amparo en el Derecbo español (en realidad, sólo el de la época republicana), Madrid, 1980, y Martín Bassols Coma, La jurisprudencia del Tribunal de Garantías Constitucionales de la II República española, Madrid, 1981. También sobre el amparo en la legislación tepublicana, Rodolfo Reyes, La defensa constitucional, Madrid, 1934, páginas 226-306, y Meilán Gil, «El Tribunal de Garantías Constitucionales de la II República», en el volumen colectivo Actas del II Symposium de Historia de la Administración, Madrid, 1971, págs. 575-579 y 583-586. 


\section{EL AMPARO CONTRA JUECES EN LA LOTC}

Con esos antecedentes podía pensarse que el recurso de amparo de la LOTC de 1979 tendría una acogida y suerte más o menos similar, y así ha sucedido: en efecto, hasta abril de 1982 el $B O E$ ha publicado 55 sentencias del TC, de las que 35, casi dos tercios, resuelven recursos de amparo; y casi la mitad de esos 35, 16 concretamente, son estimados al menos en parte.

Ahora bien, por comparación con la experiencia anterior, la «sorpresa» ha sido que de los 35 recursos de amparo, la mayor parte son precisamente contra actos de órganos judiciales: nada menos que 25, y aún ha de agregarse que de los otros diez (contra la Administración), cuatro inciden directamente en temas judiciales ${ }^{9}$.

No se trata, por supuesto, de que los jueces vulneren ahora más derechos fundamentales que hace medio siglo, o de que lo hagan en mayor medida que la Administración: lo que sucede es, en primer lugar, que las infracciones de derechos fundamentales cometidas por los jueces en el proceso pueden ser ahora muchas más que en la legislación republicana: basta comparar el frondoso art. 24 de la Constitución vigente con el verdaderamente mínimo artículo 28 de la de 1931; y así y todo, de los 25 recursos contra órganos judiciales han sido estimados 11 , mientras que se han estimado cinco de los 10 interpuestos contra órganos administrativos; en segundo lugar ha de tenerse en cuenta que, a diferencia del recurso de amparo contra jueces, el dirigido contra actos administrativos llega al TC previo el filtro que supone el recurso contencioso-administrativo; dicho de otra manera: hay no pocas vulneraciones imputables a la Administración y de las que no llega a conocer el TC, que no llegan a un recurso de amparo, porque han sido ya reparadas en el recurso contencioso-administrativo o porque ni siquiera se interpuso éste; y en tercer lugar, para entablar un recurso de amparo frente a la Administración antes hay que agotar la vía administrativa y, como acaba de decirse, interponer un recurso contencioso-administrativo, promover un proceso, un pleito contra la Administración, mientras que por producirse las vulneraciones de los jueces ya en un proceso, la persona afectada es ya (al menos casi siempre) un litigante, está ya embarcada en un juicio, y lo único que se le exige antes del recurso constitucional de amparo es que agote todas las posibilidades del proceso en cuyo seno y curso se ha producido la real o supuesta vulneración de un derecho fundamental, que emplee en la vía judicial ordinaria todos los recursos legalmente utilizables.

Dedicadas estas páginas al recurso de amparo contra jueces y tribunales, claro está que no van a ocuparse de toda la problemática que plantea ese recurso (título III, arts. 41-58 LOTC) ni, por ejemplo, de lo que es común

\footnotetext{
- No eran tan optimistas las previsiones de Garrido Falla (pág. 1698), que con lo sucedido en Alemania y porque «en la mayoría de los casos habrá habido [antes del recurso de amparo] un contencioso-administrativo previo, que es garantía suficiente para los ciudadanos», entendía que el recurso constitucional de amparo iba «a ser muy utilizado y poco atendido». Pero, como se dice en el texto, hasta ahora sólo una cuarta parte de los recursos de amparo (bueno, un poco más: 10 de 35) ha requerido un contencioso-administrativo previo.
} 
-que es casi todo- a los recursos contra autoridades judiciales y contra autoridades administrativas (legitimación, plazo, etc.), sino exclusivamente de los trazos específicos y peculiares del amparo contra actos $\mathrm{u}$ omisiones de un órgano judicial, que se contienen en el art. 44.1 LOTC.

Según este precepto, el recurso en cuestión requiere: que se hayan agotado antes los utilizables en la vía judicial, que la supuesta violación sea imputable inmediata y directamente al juez y que se haya invocado en su momento el derecho vulnerado; pero es más que conveniente, prácticamente necesario, que el análisis de esos tres requisitos (que en los números siguientes se hace en un orden cronológico y más lógico que el que se acaba de emplear para decirlos, que es el de la ley) vaya precedido del referente al supuesto mismo de que la actuación que provoca la petición de amparo constitucional se deba precisamente a un juez; y de la determinación del ámbito o haz de derechos fundamentales que puede ser lesionado por tribunales y jueces al sustanciar y resolver un proceso. En resumen, se va a tratar a continuación de estos cinco puntos:

- El órgano judicial.

- Derechos fundamentales que pueden ser afectados.

- Violación directa e inmediata.

- Invocación formal del derecho vulnerado.

- Que se haya agotado ya la vía judicial.

\section{EL ORGANO JUDICIAL}

a) Por supuesto, los órganos judiciales forman parte de «los poderes públicos del Estado» (art. 41.2 LOTC), en cuyas actuaciones puede residenciarse la vulneración de derechos fundamentales que quizá termine en un recurso de amparo constitucional, pero la expresión empleada (ya hemos visto que la ley de 1933 hablaba de «autoridades judiciales») ha llevado a preguntarse a algún autor, creo que sin necesidad, si entre esos órganos judiciales se encuentra el Consejo General del Poder Judicial ${ }^{10}$ : para mí, la respuesta

${ }^{10}$ García Manzano, «Las vías judiciales previas al recurso de amparo constitucional», en $\mathrm{El}$ Trib. Const., II, págs. 1166-1167. El argumento, nada convincente a mi parecer, es que la ley habla de «órgano judicial» y no «jurisdiccional», con lo que caben no sólo los tribunales actuando en la jurisdicción contenciosa y en la voluntaria, «sino también los órganos de gobierno de la organización judicial al actuar funciones gubernativas o extrajurisdiccionales». De todas maneras, reconoce que el citado Consejo General es un órgano constitucional no encuadrado en el poder judicial, y que el régimen de sus actos es el administrativo.

Puede que, como dice él, la elusión de órgano «jurisdiccional» en el art. 44.1 LOTC fuera y sea consciente, pero de esa conciencia no cabe deducir que también se califica de órganos judiciales a los que con toda evidencia no lo son.

Además, el uso de ambos adjetivos es, a menudo, casual, intercambiables éstos muchas veces debido simplemente al uso o a la moda; por ejemplo $-\mathrm{y}$ me parece que con dudoso acierto-: los procesalistas y judicialistas prefieren hablar de potestad jurisdiccional, son «jurisdiccionalistas», pero sigue hablándose, con razón, de poder judicial. Naturalmente, muchas leyes entienden jurisdicción en otro sentido (declarar y aplicar Derecho aun extraprocesalmente), y por eso puede decirse que la Administración está plagada de órganos jurisdiccionales (por ejemplo: el Ayuntamiento, art. 11 LRL), pues lo que monopolizan 
es indudablemente negativa, sencillamente porque el citado Consejo no es órgano judicial, es «el órgano de gobierno» del Poder Judicial (art. 122.2 de la Constitución), pero no forma parte de él; es un órgano constitucional (art. 59 LOTC); «el órgano judicial superior en todos los órdenes», es decir, la cabeza del Poder Judicial, no es el CGPJ, sino el Tribunal Supremo (art. 123.1 Const.), aunque el presidente de éste lo sea también de aquél: tangencia en la cúspide de ambas organizaciones.

Aunque especial, por estar regulado al margen de la «ordinaria» y por recubrir a todo el entramado judicial, el Consejo es verdadera Administración («órgano de gobierno», o sea, de administración, «èn particular en materia de nombramientos, ascensos, inspección y régimen disciplinario»: art. 122.2), de modo que no puede chocar que su ley orgánica (de 10 de enero de 1980, arts. 5..$^{\circ}$ y 31 y siguientes) le faculte para «dictar reglamentos sobre.su organización y funcionamiento, así como sobre el régimen del personal ý servicios y demás materias de su competencia», potestad reglamentaria que atribuye al Gobierno el art. 97 Const. y que el $40^{\circ}$ de la aún vigente Ley Orgánica del Poder. Judicial, de 15 de septiembre de 1870 , niega a los tribunales; el Consejo resuelve recursos administrativos, sus actos son recurribles en vía contencioso-administrativa ante el Tribunal Supremo, etc. ${ }^{11}$

Como ya se ha dicho, el CGPJ es, evidentemente, uno de «los poderes públicos del Estado» (art. 41.2 LOTC) que pueden violar derechos funda: mentales y provocar un recurso de amparo, pero no es órgano judicial (artículo 44) ni legislativo (art. 42), sino administrativo o, mejor, constitucional. administrativo $y$, por tanto, los recursos de amparo contra sus actos no se rigen por el art. 44 , sino por el 43 (con previo recurso contencioso ante el Tribunal Supremo), aunque dicho artículo a base de querer precisar, innecesariamente -expressa nocent-, puede alentar la confusión, pues si hubiera que aplicar literalmente el citado precepto no habría forma de interponer un recurso de amparo contra el CGPJ, porque el art. 43 regula los recursos contra actos «del Gobierno o de sus autoridades o funcionarios», y es obvio que el tan citado Consejo es una administración paralela y autónoma, jurídicamente por completo independiente del Gobierno, no es de ningún modo una autoridad de éste ${ }^{12}$.

los jueces es el proceso, pleito, litigio o juicio; «la potestad jurisdiccional en todo tipo de procesos», ... la potestad judicial. Aurelio Guaita, "Administración de Justicia'» y Administración judicial, en RDProc:, 4 (1968), págs. 11-60.

Pera Verdaguer (pág. 2102) es también concluyente: «Al hablar el legislador de órgano judicial, no se refiere a otra cosa que a los que tienen atribuidas facultades decisorias o resolutorias, esto es, al ejercicio de la jurisdicción o, si se quiere, dicho de otro modo, a quienes encarnan el poder judicial.»

En resumen: me parece bien empleado el término «judicial» en la LOTC, y forzosamente queda fuera el CGPJ, que, a la inversa de lo que propugna García Manzano, hubiera entrado o podido entrar (no según los procesalistas ni la Constitución) si se hubiese dicho «órganos jurisdiccionales», pues ejerce indudable jurisdicción (administrativa).

${ }^{11}$ Aurelio Guaita, «Los actos administrativos del Tribunal Constitucional», en El Tribunal Constitucional, II, págs. 1300-1304.

12 Aunque debe notarse que el Consejo, según el art. $49^{\circ}$ de su ley orgánica, debe remitir anualmente a las Cortes y al Gobierno una memoria sobre el estado y las actividades de la "Administración de Justicia», lo que puede interpretarse como una jusțificación y rendición de cuentas ante los otros dos poderes: 
b) Concluido el excurso a que nos ha obligado el Consejo General del Poder Judicial, ha de decirse ahora que la lectura de la LOTC lleva inequívocamente a la misma conclusión: que «órganos judiciales» son sólo y todos los «tribunales ordinarios», los de la «jurisdicción ordinaria» (art. 53 Const.). En efecto, según el art. 44.1 LOTC, han de haberse agotado antes del recurso de amparo todos los utilizables «dentro de la vía judicial» [párrafo a)], lo que indica que ya se está en dicha vía, ante jueces, en juicio; los párrafos $b$ ) y c) hablan del «proceso» en curso; y por si hubiese alguna duda, que no la hay, el art. 54 se refiere al caso «del recurso de amparo respecto de decisiones de los jueces y tribunales».

Por cierto, esa terminología, que es la habitual en la legislación española y que puede verse también en la Constitución (arts. 24.1, 118 y 126; o bien juzgados y tribunales: 117 y 122), responde a la idea, inexacta, de que «tribunal» significa órgano de tres miembros y, por extensión, órgano colegiado, mientras que juzgado significa órgano o juez unipersonal. Pero realmente tribunal indica juez, el órgano que juzga, aunque sea unipersonal o individual, el que se sienta para juzgar en el tribunal (de ahí tribuna), porque tribunal no era originariamente el juzgador, sino el lugar en y desde el que juzgaba: el estrado en que se sentaban los magistrados (también el monumento a un magistrado o un general, el arengario desde el que éste se dirigía a las tropas en campaña, el estrado del pretor en el teatro y, en general, plataforma o elevación) $\mathrm{y}$, más tarde, los magistrados mismos que se sentaban en ese estrado.

Por consiguiente, no puede chocar leer que «Pilatus... sedit pro tribunali» (Jo 19,13); que en el proceso de San Pablo, «Festus... sedit pro tribunali» (Act 25,6), es decir, Pilato (o Festo) «se sentó en el tribunal»; o que, ya antes, en el alboroto de los judíos de Corinto (también contra San Pablo), el procónsul Galión «minavit eos a tribunali», los echó del tribunal (Act 18, 12-17). Y lo mismo podemos leer actualmente en el DRAE al definir tribunal: «lugar destinado a los jueces para administrar justicia y pronunciar sentencias. 2 Ministro o ministros que conocen de los asuntos de justicia y pronuncian las sentencias. Colegiado: el que se forma con tres o más individuos por contraposición al tribunal unipersonal».

Por cierto, la Constitución emplea también la voz tribunales en la acepción amplia y exacta que comprende a los jueces y juzgados juntamente con los órganos colegiados: «El principio de unidad jurisdiccional es la base de la organización y funcionamiento de los tribunales» (art. 117.5); «El ministerio fiscal... tiene por misión... velar por la independencia de los tribunales...» (124.1); como juez quiere decir también tribunal colegiado (art. 24.2).

c) Aunque antes se ha alegado la expresión «proceso», empleada dos veces por el art. 44 LOTC, como un argumento más para apoyar la tesis de que la ley piensa exclusivamente en órganos judiciales (44.1), en jueces y tribunales (54), ha de precisarse ahora que lo sustancial no es el proceso, sino el tribunal o juez: es decir, que si hay actividad del juez en cuanto tal, aunque no haya proceso, se está en el supuesto del art. 44; así lo ha entendido el Tribunal Constitucional en un caso de jurisdicción voluntaria sobre régimen de visitas, comunicación y estancias del hijo del recurrente con respecto al 
abuelo materno (sentencia de 22 de abril de 1981, BOE de 21 de mayo ${ }^{13}$ ). Un caso distinto pero análogo y que llega al mismo resultado es el contemplado por la sentencia de 8 de febrero de 1982, BOE del 26: un juez municipal fue sancionado por la Sala de Gobierno de la Audiencia Territorial de Palma de Mallorca, «constituida en Sala de Justicia», pero en tal caso ésta actúa «como un órgano judicial que ejerce una función jurisdiccional», por lo que la expresión del art. 749 de la Ley Orgánica del Poder Judicial de 1870 de que «no se dará ulterior recurso no tiene otro significado que el de excluir una segunda instancia», lo que no implica ninguna indefensión, ni cabe tampoco recurso contencioso-administrativo, no sólo porque se excluye todo recurso, sino porque la Sala de Gobierno de la Audiencia, actuando «como Sala de Justicia», no es ciertamente la Administración (como exige para el recurso contencioso el art. $10^{\circ} \mathrm{LJCA}$ ); es decir, que el régimen disciplinario judicial se ha administrativizado a partir de la Constitución residenciándolo en el Consejo General del Poder Judicial, pero la ley orgánica de éste es posterior al auto que sancionó al recurrente y no es retroactiva, argumenta el TC, y aunque la Constitución sí estaba ya vigente al dictarse dicho auto, en esta materia su efectividad se demoraba forzosamente hasta que se dictara la Ley Orgánica del Poder Judicial o la (ya promulgada) del CGPJ ya citada.

En cambio, lógicamente, si la actividad (o inactividad) causante de la supuesta vulneración de un derecho fundamental es de un órgano administrativo, no es aplicable al art. 44 LOTC, aunque el caso ofrezca conexiones con la actuación de órganos judiciales: por ejemplo, si el Ministerio del Interior, alegando ciertos defectos formales imputables al Partido Comunista de España, marxista-leninista, solicitante de la inscripción en el correspondiente registro, aplaza y no da cumplimiento a lo dispuesto en la sentencia ya recaída en el caso ${ }^{14}$; o si el Ministerio de Justicia no resuelve la petición de recurso de revisión contra una sentencia penal, a lo que ciertamente tiene derecho el recurrente (a que se resuelva sobre su petición y se le comunique, no a que el Ministerio dé la orden de interponer el citado recurso): sentencia de 30 de marzo de 1981, BOE de 14 de abril.

Claro que sí hubiese sido aplicable (también) el art. 44 si en el proceso contencioso-administrativo previo exigido por el art. 43 para interponer recurso de amparo contra actos del Gobierno o de la Administración, el tribunal vulneró, a juicio del recurrente, un derecho fundamental (Audiencia Nacional, denegación de prueba), aunque en el caso (suspensión definitiva de dos diarios de San Sebastián) no hubo lugar a ello, toda vez que si bien se arguyó dicha violación al recurrir contra la suspensión decretada por la Administración pública, no se articuló «una pretensión congruente», no se pidió real y expresamente amparo contra la argumentada violación del tribunal, como ciertamente podían haber hecho los interesados, en cuyo supuesto «hubiera exigido un tratamiento separado» del original, es decir, separado del

${ }^{13}$ El recurso fue desestimado, $y$ en el caso habían intervenido sucesivamente uno de los juzgados y la Audiencia Territorial de Madrid y el Tribunal Supremo.

${ }_{14} \mathrm{El}$ recurso de amparo fue estimado por el TC en su sentencia de 2 de febrero de 1981, BOE del 24. Santamaría Pastor, "Una sentencia polémica sobre la vía judicial previa», en $R A P, 95$ (1981), 179-185. 
amparo pedido contra la Administración por la suspensión de los periódicos: sentencia de 16 de marzo de 1981, BOE de 14 de abril.

d) Hemos visto reiteradamente que en el supuesto del art. 44 entran todos y sólo los tribunales, pero ¿y si se trata de órganos que sin ser propia, esencial y necesariamente judiciales, pueden actuar con dicho carácter además de como órganos administrativos, que es lo que sucede, por ejemplo, con los capitanes generales de regiones militares, que reúnen la doble calidad de «representantes del ramo de la Administración del Ejército» y de «autoridades judiciales», según los arts. $7 .^{\circ}$ y $8 .^{\circ}$ de la Ley de Conflictos Jurisdiccionales de 17 de julio de 1948? Es obvio que entonces, siendo insuficiente por hipótesis el criterio subjetivo u orgánico, ha de estarse a la naturaleza de la actividad de dichas autoridades militares, lo que no siempre está claro, como se aprecia en el recurso resuelto por la sentencia de 15 de junio de 1981, BOE de 7 de julio: el capitán general de la primera región militar, en su calidad de autoridad judicial, ordenó la instrucción de un expediente judicial contra un capitán de caballería, que se tramitó y tesolvió en vía judicial; pero el Tribunal Constitucional, con cita de determinados preceptos del vigente Código de Justicia Militar, de 17 de julio de 1945, entendió que expediente y vía judicial no equivalen a procedimiento judicial y que de lo que se trataba en el caso era del régimen disciplinario:

«La propia estructura del expediente judicial no responde a la estructura de un proceso judicial de carácter penal, sino que se corresponde perfectamente con la de los expedientes administrativos en el ámbito civil, con una fase de instrucción en la que el instructor reúne funciones que en el procedimiento criminal se distribuyen entre el juez instructor y el ministerio fiscal, y una fase de resolución en la que el órgano a quien corresponde la decisión no está especializado y coincide con la propia autoridad administrativa. Las faltas militares... no forman parte en el CJM del derecho penal, sino del régimen disciplinario...»

Quizá las discusiones en esta materia se deban a la línea titubeante y anfibológica del CJM, y es posible que el Tribunal Constitucional esté en lo cierto al excluir o no dejar que se incluyan en el derecho penal militar las faltas y acotarlas en el régimen disciplinario, pues la estructura del expediente judicial (no los procedimientos o, mejor, procesos) «se corresponde perfectamente con la de los expedientes administrativos en el ámbito civil». Ahora bien, en tal caso parece que no podía fundarse el recurso de amparo en un acto u omisión de un órgano judicial» (art. 44.1 LOTC), sino en un acto de autoridad administrativo-militar dependiente del Gobierno (art. 43.1) y, por tanto, antes del amparo constitucional procedía agotar la vía judicial procedente, es decir, el recurso contencioso-administrativo (art. 53.2 Const. y disposición transitoria $2 .^{a}, 2$ LOTC). Pero la cuestión no se suscitó por nadie en este caso (que el Tribunal resolvió denegando el amparo solicitado), quizá porque después de la Capitanía General de Madrid intervino la Sala de Justicia del Consejo Supremo de Justicia Militar..., aunque tampoco esto hubiese justificado la inclusión del supuesto en el art. 44 LOTC, ya que éste exige que la vulneración de un derecho fundamental tenga «su origen inmediato y 
directo en un acto u omisión de un órgano judicial», y aquí la lesión (que el TC acaba negando) no la produjo el CSJM, sino el capitán general de la primera región, resolviendo un expediente que se corresponde perfectamente con los expedientes administrativos en el ámbito civil. No obstante -es la única explicación justificativa de lo acaecido-, aunque lo instruido fue un expediente y uno un «procedimiento judicial» (art. 207 CJM), es lo cierto que el capitán general actuó como «autoridad judicial», lo que sitúa la cuestión en el art. 44 LOTC. Por último, es de advertir que la discusión acerca de si el asunto era penal (tesis del recurrente) o disciplinario, no afectaba a su ubicación en el art. 43 o en el 44 LOTC (lo acabamos de ver), sino a las garantías que el expediente tiene en uno y otro caso ${ }^{15}$.

\section{LOS DERECHOS VULNERADOS}

Aquellos cuya lesión abre la vía del recurso de amparo son los que la Constitución denomina fundamentales y libertades públicas regulados en la sección $1 .^{a}$ del capítulo $2 .^{\circ}$ del título $I$ de la Constitución (arts. 15 a 29), incluidos el prólogo (igualdad: 14) y el epílogo (objeción de conciencia: $30.2)^{16}$.

Sobre ese punto no existe la menor duda (art. 53.2), pero puede cuestionarse si los jueces pueden vulnerar cualquiera de los que figuran en ese extenso catálogo de derechos fundamentales: algunos autores reducen las posibilidades a las que brinda el extenso y minucioso art. 24 (protección judicial) ${ }^{17}$ o incluso al caso concreto del procedimiento de babeas corpus del art. $17.4^{18}$, pero otros parecen dar a entender, con mejor criterio aunque menor contundencia de la posible, que el art. 24, en el que tan destacado protagonismo tiene el juez, es sólo el más vulnerable por él (la violación por el juez será «normalmente encuadrable en el art. 24»), lo que indica que pueden ser también otros los derechos violados ${ }^{19}$.

${ }^{15}$ Después de una argumentación poco convincente a mi juicio, el TC acabó declatando que las garantías del art. 24 Const. también se deben en el orden disciplinario..., aunque entendió que el interesado no había sido privado de ellas, lo que, lógicamente, llevaba y llevó a la desestimación del recurso.

${ }_{16}$ Claro está que, si el que se alega como infringido no tiene el carácter de derecho fundamental, el recurso es inadmisible; por ejemplo: el principio de legalidad consagrado en el art. 9.3, auto de 30 de septiembre de 1980; la irretroactividad de las normas sancionadoras no favorables o restrictivas de derechos (art. 9.3), sentencia de 7 de mayo de 1981, BOE del 21; la propiedad o la familia (arts. 33 y 39, respectivamente), sentencias de 18 de mayo de $1981, B O E$ de 16 de junio y 10 de julio de 1981 y de 13 de agosto, o la exclusividad jurisdiccional (art. 117.3), sentencia de 26 de enero de 1981, BOE de 24 de febrero.

${ }_{17}$ Castedo Alvarez, «El recurso de amparo constitucional», en El Trib. Const., I, págs. 201 y 205.

${ }_{18}$ Según Friginal (pág. 1141), es «el supuesto típico del amparo constitucional».

19 Pero, a veces, incluso parece excesivo el art. 24 como materia recurrible en amparo. García Manzano, págs. 1168-1170: «Sería improcedente acoger un sentido amplio del derecho de acceso a la tutela judicial, recogido en el art. 24 Const., que pudiera englobar como pretensiones de amparo residenciables ante el TC cuestiones tales como la denegación de examen del fondo por falta de legitimación activa, criterios sobre denegación de 
a) Además del art. 24, al que me refiero más adelante, los recurrentes, con o sin razón a juicio del TC, y conjuntamente o no con dicho precepto, han alegado en los veinticinco recursos de amparo contra jueces publicados hasta abril de 1982 la violación de estos otros derechos fundamentales:

El principio de igualdad, art. 14: sentencias de 26 de enero de 1981, $B O E$ de 24 de febrero; 30 de marzo de 1981, $B O E$ de 14 de abril, desestimado; 24 de julio de 1981, $B O E$ de 13 de agosto: litigantes obligados a actuar bajo una misma representación, defensa y asistencia de letrado, estimado; 23 de noviembre de 1981, BOE de 22 de diciembre: despido discriminatorio por afiliación sindical, estimado; sentencia de 26 de febrero de 1982, $B O E$ de 22 de marzo: pensión de jubilados tratados desigualmente por la Audiencia Territorial, estimado; sentencia de 29 de marzo de 1982, BOE de 21 de abril: aspirante a profesor de la Facultad de Derecho de la Universidad Complutense de Madrid, estimado pero por otra razón ${ }^{20}$.

Libertad religiosa, art. 16: sentencia de 26 de enero de 1981, BOE de 24 de febrero: custodia de los hijos, estimado pero por otra razón.

Derecho a la libertad y a la seguridad, art. 17.1: sentencia de 30 de enero de 1981, BOE de 24 de febrero: condenado por infracción de contrabando y delito monetario, desestimado; sentencia de 18 de mayo de 1981, $B O E$ de 16 de junio: internado por demente, desestimado.

Derechos al bonor, a la intimidad y a la propia imagen, art. 18.1: sentencia de 30 de enero de $1981, B O E$ de 24 de febrero: que la sentencia impugnada penetró «en las intenciones del recurrente sobre si el dinero entregado era para su exportación», desestimado; sentencia de 18 de mayo de 1981, BOE de 16 de junio: imputación de delitos atentatorios de su honor (asesinato) y, su padre, falta de custodia eficaz de su hijo demente, desestimado; sentencia de 1 de abril de 1982, BOE del 21: privarle de la custodia de sus hijos por acusación no probada de homosexualidad, «uno de los vicios más repugnantes y denigrantes y uno de los más repudiados por la sociedad», dice el recurrente, estimado aunque por otra razón.

Libertades de expresión y de reunión-manifestación, arts. 20 y 21: sentencia de 29 de enero de $1982, B O E$ de 26 de febrero, juicio verbal de faltas

pruebas, etc.» Pero la Constitución no autoriza esa interpretación restringida, que tampoco es la del TC.

J. I. Jiménez Hernández, «El recurso de amparo constitucional respecto de resoluciones judiciales», en El Trib. Const., II, pág. 1323. Salas Hernández precede su opinión de dudas e interrogantes de los que me parece puede perfectamente prescindirse, "Protección judicial ordinaria y recurso de amparo frente a violaciones de libertades públicas», en El Trib. Const., III, pág. 2475.

Un enfoque diverso y de interés en Sánchez Agesta, «El art. 24 Const. y el recurso de amparo», en El Trib. Const., III, págs. 2487-2496.

20 Condenados dos coautores de robo y hurto a distintas penas, el auto del TS de 5 de noviembre de 1980 entendió que el art. 14 Const. es programático y que, mientras no encarne en una ley positiva o precepto penal sustantivo, no puede fundarse en él un recurso de casación.

Pero es evidente que vincula a todos los poderes públicos, puede constituir el objeto de un recurso de amparo (art. 53) y está vigente desde la promulgación de la Constitución según la disposición derogatoria de ésta. Y, por supuesto, es protegible mediante el proceso preferente y sumario del art. 53.2 y Ley de 26 de diciembre de 1978, como ha tenido que declarar el TC en su sentencia de 29 de marzo de 1982, BOE de 21 de abril. 
por reunión tumultuosa y vociferante, con coacciones y graves insultos personales, desestimado.

Libertad de sindicación, art. 28: sentencia de 23 de noviembre de 1981, $B O E$ de 22 de diciembre: despido discriminatorio a causa de la afiliación sindical y de la participación en un proceso electoral, se estima el recurso (la Magistratura de Trabajo había declarado la nulidad del despido, pero por incumplimiento de requisitos formales).

Irretroactividad de normas penales, art. 25.1: sentencias de 30 de marzo de $1981, B O E$ de 14 de abril, y 11 de noviembre de 1981, BOE del 19.

Principios penales de legalidad y tipicidad, art. 25.1: sentencia de 30 de enero de 1981, BOE de 24 de febrero: en realidad, el recurrente había alegado la infracción del principio non bis in idem que, dice el TC, si bien no se recoge explícitamente en la Constitución, «va implícitamente unido» a los de legalidad y tipicidad.

b) Art. 24 de la Constitución. Acabamos de ver la invocación de diversos artículos de la Constitución para fundamentar recursos de amparo: 14, $16,17,18,20,21,25$ y 28 , que comprenden un total de dieciocho presuntas infracciones. Pero, como ya se ha adelantado, forzosamente el gran protagonista del amparo contra jueces tenía que ser el art. 24 en alguno de los muchos derechos que consagra como fundamentales y, en efecto, así es, pues sólo él ha motivado diecinueve recursos de los veinticinco que contra actuaciones judiciales se han publicado hasta la fecha, pues obviamente en gran parte de recursos se alegan como infringidos diversos preceptos constitucionales, es decir, como violados varios derechos fundamentales, figuren o no en el art. 24. Respecto de éste dice el TC en un caso penal que forma parte, «con carácter prevalente», del «derecho material vigente» y «que por contener una garantía constitucional ha de observarse en las sentencias de casación al ejercer el control de legalidad que corresponde al TS, como ha precisado la sentencia de 15 de abril de 1981, rec. 90/80; efectividad del art. 24 que incluso debe hacerse de oficio, en virtud del principio iura novit curia, al ser la garantía de procedimiento materia de orden público, según reiterada jurisprudencia del TS»: sentencia de 8 de febrero de 1982, BOE del 26.

Tutela efectiva de jueces y tribunales: sentencia de 26 de enero de 1981 , $B O E$ de 24 de febrero: se estima, pues el juzgado no ejerció la plenitud de jurisdicción a que le obligaban los arts. 117.3 Const. y 51 LECi (ejecución de una sentencia canónica); sentencia de 8 de junio de 1981, BOE de 7 de julio: alega el recurrente, pero sin razón, que ningún tribunal se ha pronunciado sobre el fondo del asunto; sentencia de 24 de julio de $1981, B O E$ de 13 de agosto: no le admitieron a un recluso el recurso de casación por supuesta presentación tardía, pero sí estaba dentro de plazo, se estima; sentencia de 16 de diciembre de 1981, BOE de 14 de enero de 1982: lo mismo, pero en este caso sí se rechazó fundadamente el recurso de casación; ídem, aquí el rechazado, con razón, fue el recurso contencioso-administrativo, pues la Sala de Gobierno de la Audiencia Territorial actuó constituida en Sala de Justicia, y su resolución (por su fecha: en el futuro será distinto) era irrecurrible: sentencia de 8 de febrero de 1982, BOE del 26; no se le admitió el recurso de casación penal, pero se estima en parte el amparo solicitado: sentencia de las mismas fechas que la anterior; la Audiencia Territorial de 
Madrid y luego el TS dejaron sin protección judicial infundadamente al rechazar el recurso contencioso-administrativo interpuesto con arreglo a la Ley especial de 26 de diciembre de 1978: sentencia de 29 de marzo de 1982, $B O E$ de 21 de abril; pero no se apreció indefensión en los tres recursos acumulados resueltos por la sentencia de 18 de diciembre de 1981, BOE de 14 de enero de 1982, sobre ejecución hipotecaria. Ni hay indefensión porque la decisión judicial no se ajuste a los deseos del interesado: auto de 25 de marzo de 1981 y sentencia de 8 de junio de 1981, BOE de 7 de julio.

Derecho a la defensa y asistencia de letrado: sentencia de 15 de junio de $1981, B O E$ de 7 de julio, militar, desestimado; el juzgado no suspendió el plazo para contestar la demanda hasta que se le nombrara abogado de oficio dados sus escasos recursos económicos, desestimado: sentencia de 23 de julio de 1981, BOE de 13 de agosto; no se podía imponer que todos los querellantes litigaran bajo una misma representación y defendidos por el mismo letrado, se estima: sentencia de 24 de julio de 1981, BOE de 13 de agosto.

Derecbo a ser informado de la acusación que se formule contra los procesados: sentencia de 30 de enero de 1981, BOE de 24 de febrero, contrabando, desestimado; rapto, desestimado: sentencia de 10 de abril de 1981, BOE del 25; sentencia de 15 de junio de 1981, BOE de 7 de julio, militar, desestimado; militar acusado de injurias al ejército con publicidad, se estimaría, pero ha sido ya absuelto, por lo que el amparo carece de contenido: sentencia de 10 de marzo de 1982, BOE del 22.

Derecho a un proceso público: alega; pero sin fundamento, haber sido condenado sin previo juicio oral, con infracción del principio nulla poena sine judicio: sentencia de 18 de mayo de 1981, BOE de 16 de junio.

Derecho a un proceso sin dilaciones indebidas: que infringe la Audiencia Territorial de Madrid si, pese al tiempo transcurrido y las facultades que le confiere la LJCA, no reclama eficazmente de la Administración el expediente para que pueda formularse por el interesado el recurso contencioso-administrativo que pretende: sentencia de 14 de julio de 1981, $B O E$ del 20; sobre el «derecho constitucional a un proceso sin dilaciones indebidas» y «la pronta terminación de la causa», también los autos de 16 y 24 de septiembre de $1980^{21}$.

Derecbo a un proceso con todas las garantías: entre las que se cuenta, por supuesto, la audiencia del interesado, nadie puede ser condenado sin ser oído, lo que no ocurrió realmente en el supuesto de la sentencia de 31 de marzo de 1981, BOE de 14 de abril (ejecución de sentencia contencioso-administrativa sobre aguas); pero sí en el caso resuelto por la sentencia de 8 de febrero de 1982, BOE del 26 (Fondo de Garantía de Riesgos de la Circulación, condenado a indemnizar sin haber sido parte en el juicio), que estima en parte el recurso de amparo.

Derecho a utilizar los medios de prueba pertinentes para la defensa: sen-

2t Sobre estas resoluciones y muchos otros autos (sólo existe el mandato de la publicación de las sentencias del TC, art. 164 Const.) y otras cuestiones de interés, Tomás Ramón Fernández, «Jurisprudencia constitucional, crónica de 1980», en RDPol., 11 (1981), 219-224; y Montoro Puerto, «Defectos subsanables y motivos de inadmisión en el proceso de amparo constitucional», en Bol. Inf. Min. de Justicia (1981), 1242-1243, separata de 21 págs. 
tencias de 22 de abril de 1981, BOE de 21 de mayo, y 15 de junio de 1981, $B O E$ de 7 de julio, infundados ambos recursos.

Presunción de inocencia: contrabando, desestimado: sentencia de 30 de enero de 1981, BOE de 24 de febrero; la declaración ante la policía forma parte del atestado, no equivale a una confesión que desvirtúe la presunción iuris tantum de inocencia si no se ratifica ante el juez, se estima: sentencia de 28 de julio de 1981, BOE de 13 de agosto; privado de la guarda de sus hijos por una acusación no probada de homosexualidad, se ha violado el derecho a la presunción de inocencia: sentencia de 1 de abril de 1982, BOE del 21.

Como se habrá observado en la sintética y compendiada relación que antecede, todos los órdenes jurisdiccionales han suministrado ya materia para el recurso de amparo: la jurisdicción civil está presente en cuatro casos, más uno de jurisdicción voluntaria; la penal, en once; la contencioso-administrativa, en seis; la laboral, én dos (uno de ellos es también de lo contenciosoadministrativo), y la militar o penal-militar, en otros dos.

c) A otro punto he de referirme antes de concluir este epígrafe, y es que, como habían advertido ya algunos autores ${ }^{22}$, la violación de un derecho fundamental por el juez puede producirse precisamente en el recurso contencioso-administrativo interpuesto para «agotar la vía judicial procedente» y poder interponer luego en su caso el recurso de amparo constitucional; es lo que podía haber sucedido en el asunto resuelto por la ya citada sentencia de 16 de marzo de 1981, BOE de 14 de abril, pues según los recurrentes, en el recurso contencioso contra una resolución del Ministerio de Cultura, la Audiencia Nacional había denegado la prueba propuesta por ellos con infracción del art. 24.2 Const., lo que hubiese originado un segundo recurso de amparo (éste contra la decisión de la Audiencia) que «hubiera exigido un tratamiento separado», aunque se había alegado la infracción en el mismo escrito del recurso de amparo contra la Administración, pero no hubo lugar a ello, pues a pesar de su alegación o denuncia, los interesados sólo pidieron amparo contra el acto de la Administración y no contra la Audiencia Nacional: «No es ésta la voluntad de los recurrentes. Una demanda de amparo originada en una supuesta indefensión hubiera exigido una pretensión congruente, que no se ha hechò, concluye el Tribunal Constitucional.

\section{IMPUTACION DIRECTA E INMEDIATA AL JUEZ}

El art. 44 exige que en los recursos de amparo contra jueces o tribunales se dé, entre otros, este requisito: «b) que la violación del derecho o libertad sea imputable de modo inmediato y directo a una acción u omisión del órgano judicial con independencia de los hechos que dieron lugat al proceso en que aquéllos se produjeron, acerca de los que, en ningún caso, entrará a conocer el Tribunal Constitucional», lo que se reproduce en buena medida en el art. 54: «Cuando la Sala conozca del recurso de amparo respecto de deci-

¿ García Manzano, págs. 1168-1169; Jiménez Hernández, pág. 1323; Pera Verdaguer, págs. 2100 y 2107. 
siones de los jueces y tribunales, limitará su función a concretar si se han violado derechos o libertades y se abstendrá de cualquier otra consideración sobre la actuación de los órganos jurisdiccionales» ${ }^{23}$.

Ambos preceptos son consecuencia, desarrollo y concreción de los números 1 y 3 del art. 117 Const., según el cual, «la justicia... se administra... por jueces y magistrados integrantes del poder judicial...» y «el ejercicio de la potestad jurisdiccional en todo tipo de procesos... corresponde exclusivamente a los juzgados y tribunales determinados por las leyes...».

Congruentemente, esos principios enmarcan la jurisprudencia del TC, que puede sintetizarse así:

a) El recurso de amparo no es una nueva o tercera instancia, se basa en hechos ya establecidos que el TC no puede en modo alguno revisar, pues ha de limitarse a comprobar y declarar si se ha violado o no un derecho fundamental, y su Ley Orgánica le veda conocer de los hechos que dieron lugar al proceso: autos de 1 de octubre (tres) y 26 de noviembre de 1980 , y 22 de julio y 4 de noviembre (dos) de 1981; y sentencias de 30 de enero, $B O E$ de 24 de febrero; 30 de marzo, $B O E$ de 14 de abril; y 18 de mayo de 1981, $B O E$ de 16 de junio; y 29 de enero, $B O E$ de 26 de febrero; y 29 de marzo y 1 de abril de 1982, BOE de 21 de abril.

b) La alegada violación de un derecho fundamental ha de ser imputable de modo inmediato y directo, precisa y exclusivamente, al tribunal que conoce del asunto, no preexistente a la intervención judicial: autos de 30 de septiembre y 1 de octubre de 1980 , y 4 de noviembre de 1981; y sentencias de 26 y 30 de enero de 1981, BOE de 24 de febrero; de 31 de marzo de 1981, $B O E$ de 14 de abril, en la que se lee:

«Frente al argumento de que la supuesta violación del derecho invocado no es imputable directa e inmediatamente a las resoluciones judiciales objeto del recurso de amparo, cabe oponer que lo que importa a efectos de admisibilidad del propio recurso, de acuerdo con el artículo 44.1.b) LOTC, es que tal imputación se haga por el demandante de modo que, al menos aparentemente, se deduzca de su exposición una relación inmediata y directa de causalidad entre la violación del derecho o libertad y la acción u omisión del órgano judicial, dejando naturalmente al margen la cuestión - por ser de fondo y tener que plantearse en orden a la estimación o denegación del amparo- de si se ha dado o no, en la realidad de los hechos, tal relación de causalidad. Y lo cierto es que el demandante impugna formalmente unas resoluciones

${ }^{23}$ Para González Pérez (pág. 326), el art. 54 comprende tanto a los recursos contra actos administrativos (art. 43 LOTC) como contra actos de jueces (art. 44); pero parece claro que alude sólo a éstos, pues habla «del recurso de amparo respecto de decisiones de los jueces y tribunales». Y Jiménez Hernández (págs. 1236-1327) entiende que abarca incluso a las sentencias que se dicten respecto de actos de particulares; pero ya se ha dicho (nota 4) que tal recurso de amparo es imposible, no existe.

Por su parte, Rubio y Aragón (págs. 880-881), con excesiva susceptibilidad a mi juicio, dicen del último inciso del art. 54 [en realidad innecesario y repetitivo del 44.1.b)]: «Párrafo tan desafortunado no resulta muy congruente con el altísimo papel que al Tribunal [Constitucional] encomiendan la Constitución y la propia Ley Orgánica [del TC] en su art. 1. ${ }^{\circ} \%$ 
judiciales - los autos dictados en el proceso de ejecución de la sentencia firme- a los que imputa - con razón o sin ella, éste es otro temala violación del derecho a una tutela judicial efectiva»;

y sentencia de 7 de mayo de 1981, BOE del 21, de la que también es oportuno reproducir unas frases, como ejemplo de resultado distinto y. de diferente cuestión relativa a la materia que nos ocupa ahora:

«Al citar como infringido el art. 25.1 Const., se invoca el principio de reserva de ley y, por tanto, ya sea que la violación se entienda producida por el decreto que sirvió de base a la imposición de la sanción o por el acto administrativo de aplicación del citado decreto, se invoca en todo caso la inconstitucionalidad de éste, pero en ningún caso supondría una violación del orden constitucional producida inmediata y directamente por el órgano judicial.»

c) Ese caso nos introduce en el tema de que si la presunta violación se debe a un órgano administrativo, el posible recurso de amparo se canalizará por el art. 43 y no el 44 LOTC, por tanto, con recurso contencioso previo al de amparo, pero la resolución del contencioso que confirma el acto recurrido no es impugnable en amparo constitucional, pues la posible violación del derecho no es imputable al tribunal, sino a la Administración: sentencia de 16 de marzo de 1981, BOE de 14 de abril:

«Estas decisiones [judiciales] desestimatorias no alteran la situación jurídica creada por el acto de la Administración, presuntamente lesivo de un derecho fundamental, y no son, por tanto, en sí mismas, causa de lesión. Otra interpretación llevaría a entender, en definitiva, que no hay más actos u omisiones atacables en vía de amparo constitucional que los actos u omisiones de los órganos judiciales»;

sentencia de 7 de mayo de 1981, BOE del 21: impuesta una multa a la Caja de Ahorros de Sabadell por incumplimiento de disposiciones sobre seguridad del establecimiento y recurrida la sanción del Ministerio del Interior, el recurso contencioso fue estimado por la Audiencia Nacional, pero apelada la sentencia de ésta fue revocada por el TS y, en consecuencia, confirmado el acto impugnado... que fue el causante de la lesión si la hubo, en modo alguno es ésta imputable directa e inmediatamente al TS; y sentencia de 26 de febrero de 1982, BOE de 22 de marzo:

«Cuando se impugna en vía de amparo una sentencia de la jurisdicción contencioso-administrativa puede resultar que la correcta identificación del acto al que haya de atribuirse la hipotética vulneración del precepto constitucional sea precisamente el acto originario de la Administración y no el posterior del tribunal, que resulta total o parcialmente confirmatorio de aquél, singularmente cuando la eventual estimación de la pretensión lo sería precisamente en cuanto la sentitencia es confirmatoria, es decir, para corregir el acto administrativo anterior, viciado de inconstitucionalidad.» 


\section{INVOCACION DEL DERECHO VULNERADO}

Entre los requisitos del recurso de amparo contra jueces figura éste en el art. 44.1.c) LOTC: «Que se baya invocado formalmente en el proceso el derecho constitucional vulnerado, tan pronto como, una vez conocida la violación, hubiere lugar para ello» ${ }^{24}$.

El precepto procede sin duda del art. $1.696 \mathrm{LECi}^{25}$ y su razón es bien simple: el recurso de amparo es un intento y pretensión de remedio in altissimis, pero el juez natural y primero de las supuestas lesiones de derechos fundamentales, como de los demás, es el juez ordinario, y a él ha de pedirse en primer lugar la protección contra un acto suyo o de un juez inferior tan pronto como sea posible: el requisito en cuestión

«tiende a dar oportunidad al propio órgano judicial para que pueda argumentar y pronunciarse sobre lo que luego constituye el motivo y fundamento del amparo»: auto de 17 de diciembre de 1980;

«tiene como finalidad y razón de ser hacer posible el restablecimiento del derecho constitucional vulnerado dentro de la propia jurisdicción ordinaria, al ser el amparo un medio último y subsidiario de garantías: auto de 31 de julio de 1981 .

En términos muy parecidos, los de 18 y 25 de noviembre del mismo año, $\mathrm{y}$ añade este último una segunda justificación:

«evitar que el recurso se convierta en una nueva instancia en la que, con el pretexto de una supuesta violación de un derecho llevada ante el TC, se pretenda en realidad obtener una nueva resolución favorable a una pretensión ajena al ámbito constitucional, y que planteada en su día en el ámbito judicial que le era propio, hubiera sido, sin embargo, desestimada en este último».

«El requisito... está directamente ordenado a facilitar que en el proceso judicial, vía ordinaria de la defensa de los derechos y libertades públicas, quien conoce de él pueda satisfacer tal derecho o libertad haciendo innecesario el acceso a sede constitucional»: sentencia de 26 de enero de 1981, BOE de 24 de febrero.

${ }^{24}$ El texto transcrito se debe a una enmienda del Senado, pues la redacción del proyecto era ligetamente distinta: "Que se bubiese becho invocación formal dentro del proceso judicial correspondiente del derecho constitucional vulnerado tan pronto como, una vez conocida la violación, hubiera lugar para ello.» Fue ésa la única alteración experimentada por el proyecto del Gobierno en el que acabó siendo art. 44.

${ }_{25}$ «Para que puedan ser admitidos los recursos de casación fundados en quebrantamiento de forma será indispensable que se haya pedido la subsanación de la falta en la instancia en que se cometió; y si hubiera ocurrido en la primera, que se haya reproducido la petición en la segunda conforme a lo prevenido en el art. 859.»

Análogo era el art. 914 LECr, derogado por Ley de 16 de julio de 1949: «En los casos del art. 911 no será admisible el recurso [de casación por quebrantamiento de forma] si la parte que intente interponerlo no hubiese reclamado la subsanación de la falta mediante los recursos procedentes o mediante la oportuna protesta.» 
La invocación que exige la ley

«tiende a crear la oportunidad de que el propio órgano judicial se pronuncie sobre dicho extremo [el derecho constitucional vulnerado] para argumentar sobre la posible infracción del derecho o libertad»: sentencia de 8 de febrero de 1982, BOE del 26.

En fin, la más reciente resolución sobre el punto que nos ocupa destaca, como la ya citada de 26 de enero de 1981, la colaboración de los propios interesados con los tribunales, la ayuda (facilitar) que les prestan con la invocación formal exigida por la ley:

«El art. 44.1.c) LOTC tiene el sentido de facilitar que los jueces y tribunales puedan cumplir su función de tutelar los derechos y libertades susceptibles de amparo constitucional, por lo que el principio iura novit curia queda reforzado por la necesidad de una invocación formal que - de acuerdo con el espíritu de la ley- ha de ser suficiente para que el juzgador pueda valorar en términos de derecho la cuestión suscitada»: sentencia de 29 de marzo de 1982, BOE de 21 de abril ${ }^{26}$.

Cuanto antecede es muy razonable, pero con tal de que se interprete con la necesaria flexibilidad y sin perder de vista que un formalismo excesivo sería lo más contrario al empeño que ha puesto la Constitución en articular todo un extenso y multiforme sistema de garantías para los derechos fundamentales y libertades públicas ${ }^{27}$, sería reincidir en la antigua ( $\mathrm{y}$ a veces actual) jurisprudencia que extrapolando e hipervalorando el carácter revisor del recurso contencioso-administrativo bloquea y yugula con cierta frecuencia muchas de sus exigencias y posibilidades en contra sin duda del espíritu de la LJCA; por supuesto, en el recurso de amparo se revisa una actuación u omisión judicial, pero también conviene tener presente la misión propia de los tribunales (amparo de los derechos), su conocimiento del derecho (iura novit curia), que la lesión del derecho pueden producirla in extremis y con escasas posibilidades de reclamar en tiempo y forma ante ellos, que la omisión del requisito legal puede ser en la mayor parte de los casos un defecto desdeñable (o casi) al reducirse a no haber facilitado al tribunal el cumplimiento de su función de tutelar los derechos y libertades de los particulares y, en suma, que el carácter revisor del recurso de amparo ha de referirse más a la actuación del tribunal ordinario respecto de la alegada vulneración que respecto de la invocación formal que se exige del recurrente ${ }^{28}$.

En la jurisprudencia del TC se pueden detectar fácilmente dos líneas dis-

\footnotetext{
${ }^{26}$ En otras ocasiones el TC se ha limitado a recordar y exigir el requisito con la consecuencia de la inadmisibilidad del recurso en caso de incumplimiento: autos de 19 y 24 de septiembre y 15 de octubre de 1980 , y 23 de septiembre y 9 de diciembre de 1981 .

${ }_{27}$ Aurelio Guaita, Régimen de los derechos constitucionales, escrito para el libro homenaje al profesor Diego Sevilla en esta R. D. Pol., 13 (1982), 75-93.

${ }_{28}$ González Pérez .(pág. 309) dice a este respecto: «Esperemos que este requisito "formal' no se interprete por el TC con demasiado 'formalismo', haciendo ineficaz esta garantía jurisdiccional.»
} 
tintas: de una parte, la que podemos llamar dura, inflexible, rígida, que desemboca a menudo en la inadmisión del recurso; de otra, la más flexible y antiformalista, que mira más a la realización de la justicia que al cumplimiento de la ley.

Como ejemplo de lo primero puede citarse el declarado carácter insubsanable de la omisión del requisito de la invocación formal, pues lo que puede subsanarse es exclusivamente el no haber acreditado haber cumplido el requisito, no el incumplimiento de éste: auto de 24 de septiembre de $1980^{29}$; el requisito ha de cumplirse durante el proceso, no extinguido ya éste: auto de 17 de junio de 1981; ha de hacerse tan pronto sea conocida la presunta vulneración y por medio de un trámite o recurso admisible o viable, y no puede admitirse

«si el acto de la parte en que se formula la invocación está llamado de antemano a no producir efecto alguno»: auto de 18 de noviembre de 1981.

«Es necesario que la determinación del momento en que se ha de efectuar la invocación exigida no quede a la libre voluntad de la parte, sino que, con una interpretación finalista, se efectúe en el término exigido por los criterios de razonabilidad y buena fe, caracterizados por la proximidad al conocimiento de la vulneración y por la eventual potencialidad de la protesta; lo cual implica que no se efectúe tampoco en trámite procesal que por su falta de previsión legal [un recurso «inventado»] esté necesariamente abocado a la mera inadmisión»: auto de 25 de noviembre de 1981.

Pero si se alega el incumplimiento del requisito, por supuesto el Tribunal ha de oír sobre ese extremo al recurrente antes de resolver; sentencia de 16 de diciembre de 1981, $B O E$ de 14 de enero de 1982; la invocación exigida por la ley se puede hacer en la vista oral de la apelación: auto de 2 de diciembre de 1981; o al formularse el recurso de casación: auto de 31 de julio de 1981; naturalmente, el requisito sólo es exigible desde la entrada en vigor de la LOTC: auto de 17 de diciembre de 1980, y sentencias de 31 de marzo de 1981, BOE de 14 de abril, y 8 de febrero de 1982, BOE del 26: desde la LOTC, dice esta última sentencia,

«pero no antes, pues al haber sido un requisito establecido por ésta [la LOTC], su exigencia anticipada haría dotar de eficacia retroactiva a una disposición limitativa del derecho no prevista por la citada ley y contraria al art. 9.3 de la Constitución Española, como ha tenido ocasión de señalar este Tribunal en autos de 18 de septiembre y 17 de diciembre de 1980 , y sentencias de 26 y 30 de enero, y 30 y 31 de marzo de 1981».

En otras ocasiones, discutido y negado el cumplimiento del requisito, el TC se pronuncia por la afirmativa: pues en el escrito de conclusiones en el juzgado se invocaron por el recurrente los arts. 17.1 y 117.3 Const., en la

${ }^{2}$ Una razonable y razonada crítica de ese auto en Tomás Ramón Fernández, páginas 222-223. 
apelación aludió al principio non bis in idem, y la Audiencia Nacional afirma en su sentencia que no vulneró el principio de presunción de inocencia del 24 ni el de legalidad del 25 ,

«lo que ha de entenderse como respuesta del órgano judicial a una alegación previa»: sentencia de 30 de enero de 1981, BOE de 24 de febrero.

El recurrente alegó en la vía contencioso-administrativa

«que el derecho del art. 14 Const. no puede quedar sin protección jurisdiccional por imponerlo así el art. 53.2 de la misma, señalando además que la Constitución vincula a todos los poderes públicos. El derecho a la protección jurisdiccional está expresamente invocado, de manera formal, y éste es el derecho constitucional susceptible de amparo supuestamente vulnerado. El tecurrente no cita expresamente el artículo 24 Const., pero no podemos interpretar el 44.1.c) [de la LOTC] en sentido formal y contrario al principio pro actione, sino que, por el contrario, a partir del planteamiento explícito de la cuestión jurídicoconstitucional hay que entender que juega con toda su plenitud el principio iura novit curiäs: sentencia de 29 de marzo de 1982, BOE de 21 de abril.

En fin, ante la diversidad, más aparente que real y más formal que sustancial, de los arts. 44.1.c) (requisito previo al recurso de amparo: «que se haya invocado formalmente en el proceso el derecho constitucional vulnerado») y 49.1 (en la demanda de amparo «se citarán los preceptos constitucionales que se estimen infringidos») ${ }^{30}$, con muy buen criterio, en mi opinión, al TC, como acabamos de ver en la sentencia de 29 de marzo de 1982, le parece suficiente que en el proceso se hubiesen invocado los derechos supuestamente infringidos, aunque en la demanda de amparo no se citara el correspondiente precepto constitucional; y lo mismo con anterioridad en al menos estos dos casos:

«En cuanto al incumplimiento del requisito exigido por el artículo 44.1.c) LOTC, hay que entender que tal exigencia está referida no a la invocación del precepto, sino del derecho constitucional vulnerado y que tal invocación se cumplió, en este caso, de modo suficiente para que pudiera ser examinada por la Audiencia provincial de Córdoba cuando el recurrente, en diversos momentos de los recursos interpuestos ante ella, aludió a lo que él entendía que constituía una aplicación

\footnotetext{
${ }^{30}$ Según Montoro Puerto (pág. 20), «son dos conceptos distintos, cuya diferenciación no se ha obtenido, hasta el momento, suficientemente, y que habrá de tenerse en cuenta particularmente en aquellos casos en que se mencione un precepto constitucional, en el curso de un proceso, sin fijar el 'derecho' lesionado, o en la demanda de. amparo se mencione el derecho que se tiene por vulnerado y no se haga expresa mención del precepto».
} 
desigual de la ley en su perjuicio»: sentencia de 30 de marzo de 1981, $B O E$ de 14 de abril; y

«La invocación en el proceso del derecho constitucional vulnerado que exige el art. 44.1.c), ya se efectúe con la cita directa y textual del precepto, o con el señalamiento de su contenido esencial o básico, en cuanto tiende a crear la oportunidad de que el propio órgano judicial se pronuncie sobre dicho extremo para argumentar sobre la posible infracción del derecho o libertad...»: sentencia de 8 de febrero de 1982, $B O E$ del 26.

En resumen: creo que lo decisivo es la determinación, concreción y perfecta identificabilidad del derecho fundamental presuntamente vulnerado, base y razón del recurso de amparo, de modo que debe ser indiferente la cita del precepto (por ejemplo, «art. 14», «art. 22», ...) o la invocación del derecho (por ejemplo, igualdad ante la ley, derecho de asociación, ...); lo que quiere decir también que no basta la cita de un artículo de la Constitución cuando, como sucede con frecuencia, contiene diversos derechos; por ejemplo, artículos $15,18,19,20,23,27,28, \ldots y$, muy especialmente, $y$. fundamental para nuestro asunto, el art. 24, pero sí debe bastar la invocación inconfundible de un derecho, por ejemplo, a la integridad física o moral, a la presunción de inocencia, ... aunque no se cite el art. 15, el $24, \ldots$

\section{QUE SE HAYAN AGOTADO TODOS LOS RECURSOS UTILIZABLES DENTRO DE LA VIA JUDICIAL}

Es el último requisito que vamos a examinar y que la ley exige (por cierto, en primer término: art. 44.1.a) con carácter previo a la interposición del recurso de amparo.

A diferencia del amparo en materia de objeción de conciencia (art. 45 LOTC) o contra actos no legislativos de las Cortes (art. 42 ídem: en este caso, en realidad, inconstitucionalmente: cfr. 53.2 Const.: antes del recurso de amparo ante el TC, proceso ante los tribunales ordinarios), cuando se impugnan actos de órganos administrativos o judiciales,

«el recurso de amparo... no es, en los casos de los arts. 43 y 44 LOTC, directo, sino que al TC sólo puede acudirse una vez que se haya agotado la vía judicial procedente»: auto de 16 de septiembre de 1980 .

No obstante ser cierta la afirmación del TC en ese auto, aparecer la expresión «vía judicial» tanto en el art. 43 como en el 44 , y ser en ambos casos la razón y finalidad las mismas, los supuestos no son totalmente idénticos, pues en el del art. 43 (amparo contra el poder ejecutivo) antes del recurso constitucional de amparo hay que agotar «la vía judicial procedente», hay que promover un verdadero proceso de amparo ante la jurisdicción ordinaria (un recurso contencioso-administrativo) porque ya ba babido la real o hipotética lesión del derecho fundamental que desencadena dicho proceso, mientras que en el supuesto del art. 44 (amparo contra el poder judicial), 
por surgir la vulneración del derecho en un proceso ya en curso (y, en principio, ajeno al tema de los derechos fundamentales) no hay, claro es, que promover un proceso, no ha de recorrerse de principio a fin una vía judicial en la que ya se está, sino que ha de agotarse lo que en ella quede por recorrer, hay que agotar «todos los recursos utilizables dentro de la vía judicial» ${ }^{31}$.

De todos modos, tampoco sería pertinente insistir en las diferencias entre ambos casos, pues en los dos encontramos el mismo concepto básico: agotar la vía judicial: en un caso, la «procedente» (y precedente); en otro, mediante los recursos utilizables (... todavía: ninguno si la lesión se produce in extremis, porque ya está agotada la vía judicial).

La razón de esa exigencia nos es ya conocida, pues es la misma que en el requisito examinado en el epígrafe anterior: apurar todas las posibilidades de la jurisdicción ordinaria, que es el protector nato y primero de todos los derechos (art. 117.3 Const.), dejando al recurso de amparo y al TC como último y subsidiario remedio, sólo para cuando haya sido insatisfactoria la actuación de los tribunales ordinarios.

«Los recursos utilizables». ¿Cuáles son? Varían según los casos y la jurisdicción de que se trate, claro es, los previstos en las diversas leyes procesales (LECi, LECr, LJCA, LPL, CJM...): en la jurisdicción penal, por ejemplo, el de reforma y quizá el de apelación: autos de 24 de septiembre y 15 de octubre de 1980; en la laboral, los de reposición y queja (además del de suplicación): auto de 4 de marzo de 1981; en la civill, el de apelación y, como en las otras dos, el de casación; también el de apelación en la contenciosoadministrativa; etc. ${ }^{32}$.

${ }^{31}$ En la discusión parlamentaria de la Ley Orgánica del Tribunal de Garantías Constitucionales de 14 de junio de. 1933 «se planteó por el señor Elola -quien, por cierto, era distinguido magistrado y había sido fiscal general de la República- la necesidad de diferenciar los supuestos agravios de las autoridades judiciales de los de las demás autoridades, exigiéndose en aquel caso la obligación de agotar integramente los recursos judiciales que correspondiesen. La Comisión, por boca del señor Gomáriz, contestó oponiéndose a tal tesis por considerar que, en ese caso, "el recurso de amparo sería una ficción. Supongamos que un juez, sin auto motivado, vulnerando la Ley de Enjuiciamiento, retiene siete días en prisión a un ciudadano. Según Su Señoría (el señor Elola), tiene que agotar los recursos legales: petición al juzgado, reforma del auto de prisión, apelación subsidiaria ante la Audiencia, etc. Total, que se pasa en la cárcel toda su vida'. Este criterio fue el que finalmente prosperó, y en el texto de la ley no se hizo distinción alguna. No se trata, en efecto, de autorizar la intromisión de amparo en el ámbito de la ordinaria, sino de garantizar una protección rápida y eficaz frente a una violación de derechos» (García Ruiz, pág. 98).

De modo semejante y en el mismo libro (págs. 283-284), Pérez Tremps dice, a propósito del requisito que nos ocupa, pero ya en la LOTC: «La razón que justifica tal requisito viene determinada por la intención de evitar conflictos entre las dos instancias jurisdiccionales.»

${ }_{32}$ Pera Verdaguer (págs. 2106-2107) entiende que «no es lógico ni fundado sostener que en la cadena de recursos ha de llegarse siempre al pináculo» cuando con ello no se pueda teparar la violación de derechos, y que cuando se trate de defectos de procedimiento, lo lógico sería utilizar la vía de los incidentes de nulidad de actuaciones.

Pero lo que exigen la ley y la jurisprudencia es agotar los recursos utilizables. Además de las resoluciones citadas en el texto: autos de 24 de septiembre de 1980 , y 14 de enero, 29 de abril, 17 de junio, 1 de julio y 11 de octubre de 1981 . 
En cambio, y creo que acertadamente ${ }^{33}$, no se exige haber interpuesto el de revisión, siempre sin duda extraordinario, toda vez que es por graves y raras causas tasadas (cohecho, falso testimonio..., que no concurren casi nunca) y en todo caso contra sentencias firmes: sentencia de 28 de julio de 1981, BOE de 13 de agosto; y el auto de 1 de julio de 1981 habla de «los medios de impugnación normal existentes»; tampoco es exigible «el remedio excepcional previsto en el art. 102.1.b) LJCA para el evento de sentencias contradictorias»: sentencia de 11 de junio de 1981, BOE del 16, si bien este caso era contra la Administración, se aplicaba el art. 43 LOTC, no el 44.

Para finalizar, es oportuno aludir al criterio del TC acerca de otras varias cuestiones concretas que presenta el requisito de agotar antes del de amparo todos los recursos utilizables en la vía judicial:

«En cuanto a la afirmación de que no se han agotado todos los recursos pertinentes utilizables dentro de la vía judicial, porque lo que debió impugnar el demandante en su momento, a través del correspondiente incidente de nulidad de actuaciones, fueron las sentencias y no los autos dictados en el curso del procedimiento de ejecución de aquéllas, es de destacar que ésta es una cuestión ligada al problema de fondo del presente recurso de amparo y que a efectos de la admisión o no del mismo lo que ha de juzgarse exclusivamente es si contra las actuaciones judiciales directamente impugnadas ante este TC - las tendentes a la ejecución de dicha sentencia firme- se han agotado, como prescribe el art. 44.1.a) LOTC, todos los recursos utilizables dentro de la vía judicial.

Pues bien, habida cuenta de que contra el auto de 22 de noviembre de 1978 de la sala de lo contencioso-administrativo de la Audiencia Territorial de Valladolid, la ahora demandante interpuso recurso de apelación ante el TS, que éste resolvió por auto de 4 de junio de 1980 en sentido desestimatorio, debe considerarse agotada la vía judicial, dado que contra el último auto no procedía recurso alguno»: sentencia de 31 de marzo de 1981, BOE de 14 de abril.

Huelga decir que los recursos utilizables en vía judicial han de interponerse dentro de plazo, pero...:

«La interposición del recurso de súplica fuera del plazo señalado en la LECr lleva consigo, en principio, el incumplimiento del requisito previsto en el art. 44.1.a) LOTC: agotamiento de la vía judicial previa. Pues dicho requisito ha de ser entendido como la utilización en forma del correspondiente recurso, sin dar lugar a la caducidad del derecho de impugnar la resolución judicial por el transcurso del tiempo al que se supedita su ejercicio, ya que ello equivale a hacer inviable el recurso, evitando que pueda desplegar su normal eficacia revisora.

Sin embargo, en el presente caso, según se desprende del acuer-

${ }^{33}$ Lo mismo opina García Manzano (pág. 1168); en contra, Montoro (pág. 17), con el argumento de que sólo la LJCA lo califica de extraordinario. 
do 3. del auto de la Audiencia Provincial... impugnado, el recurso de súplica presentado fuera de plazo hubiera sido en cualquier caso desestimado, pues se hacen extensibles a los hoy recurrentes las razones por las que se desestimaron los recursos de súplica de quienes los interpusieron oportunamente.

Al haberse manifestado en este caso la voluntad del órgano jurisdiccional sobre el mismo fondo de la cuestión planteada, la de entenderse que la finalidad del requisito exigido en el art. 44.1.a) LOTC se ha cumplido, pues el recurso hubiera sido en cualquier caso ineficaz para reparar la supuesta vulneración del derecho constitucional aducido y no hubiera podido, por tanto, conseguirse a través de la vía judicial el restablecimiento del recurrente en la integridad de su derecho violado. Esta interpretación teleológica de dicho requisito debe prevalecer sobre la mera consideración del mismo como un obstáculo formal que en todo caso haya de ser superado»: auto de 11 de febrero de 1981.

Es evidente que los interesados han de interponer en la vía judicial sólo los recursos utilizables, los procedentes, sin intentar alargar y estirar aquella vía anterior al de amparo con recursos absolutamente impresentables. Pero también aquí ha de matizarse y sienta buena jurisprudencia el TC:

«Habiendo utilizado el recurrente la súplica contra la providencia de 5 de febrero de 1980 y preparado el recurso de casación contra el auto de la Audiencia desestimatorio de la súplica, el TS al resolver el recurso de queja interpuesto contra el auto de la Audiencia que declaró no haber lugar a preparar el de casación, confirmó este último auto y declaró la radical incompatibilidad entre los recursos de súplica y casación. Pero esta resolución no implica que el recurso de casación hubiera debido ser considerado por el recurrente, antes de interponerlo, como no utilizable y que, por tanto, el plazo de veinte días para presentar el recurso de amparo constitucional ${ }^{34}$ hubiera debido computarse, en aplicación de la disposición transitoria $2 .^{a}, 1$ LOTC 'desde el día en que quedó constituido el Tribunal', ya que no lo estaba cuando se resolvió y notificó en recurso de súplica, último utilizable en opinión del Ministerio Fiscal. La expresión 'recursos utilizables' del art. 44.1.a) LOTC

${ }^{34}$ Por cierto, con criterio, en mi opinión, más duro que acettado (y lo mismo opinan otros autores), el TC ha entendido que el plazo en cuestión es de caducidad y días naturales: «Es un plazo de derecho sustantivo, de caducidad legal, que no queda impedido o suspendido por la inhabilidad de alguno de los días que forman parte de él, y que el art. 304 LECi en relación con el 80 LOTC, sólo es aplicable al cómputo de los plazos establecidos para la secuencia del procedimiento cuando ya éste ha sido abierto, pero no como condición del ejercicio de la acción que pone en marcha tal procedimiento»: autos de 18 de noviembre y 16 de diciembre de 1981 .

Parece palmario el contraste entre esa doctrina y la sentada en las sentencias que se están citando precisamente ahora en el texto, que, con toda razón a mi juicio, pasan por alto mayores defectos $y$, atendiendo a la finalidad del amparo constitucional y lo que se juegan los interesados, no para mientes en cuestiones sobre si' se ha descontado o no del plazo improcedentemente un domingo, y declara la admisibilidad del recurso siempre que es posible mediante una argumentación lógica, justa y razonable. Recuérdese, además, que los autos no se publican en el BOE, y sientan doctrina que no conocen los letrados. 
hay que entenderla dentro de los términos razonables propios de la diligencia de quien asume la dirección letrada de cada caso concreto. En éste no puede decirse que la interposición de casación fuese temeraria o que al prepararla el recurrente cometiera un manifiesto exceso de diligencia pues, en fin de cuentas, la Sala $2 .^{a}$ del TS había confirmado en su día la sentencia de la Audiencia de 18 de noviembre de 1977, cuyos efectos relativos a la privación de libertad de XYZ se trataba de combatir, y es por ello comprensible que el letrado encargado de la dirección técnica del caso agotase la posibilidad de acudir de nuevo, aunque fuese por esta nueva vía, ante aquella Sala del TS, por lo que la casación, aun fundadamente rechazada por dicho Tribunal, no puede decirse que fuese no utilizable desde el parcial y diligente punto de vista del recurrente. En consecuencia, el plazo del art. 44.2 LOTC debe contarse desde la notificación de la resolución del último recurso utilizado, que fue el de queja, $\mathrm{y}$, por tanto, la demanda de amparo se interpuso dentro de plazo»: sentencia de 30 de marzo de 1981, BOE de 14 de abril.

Por supuesto, el requisito en cuestión sólo puede exigirse después de la entrada en vigor de la LOTC, norma que lo estableció, y no cuando la sentencia impugnada es anterior incluso a la Constitución, pues

«del no ejercicio de los recursos reconocidos por la LECr no puede deducirse con certeza en esas circunstancias la renuncia a entablar un nuevo y muy peculiar recurso como es el de amparo, una vez que éste fuera admitido en la Constitución y regulado por la LOTC»: sentencia de 18 de mayo de 1981, BOE de 16 de junio.

En fin, es sobremanera lógico que no sólo han de haberse interpuesto todos los recursos utilizables en la vía judicial, sino que, también antes del de amparo, han de haberse resuelto ya dichos recursos, y si el interesado interpuso el de revisión, mientras no sea resuelto éste no puede acudir al Tribunal Constitucional: autos de 4 de febrero y 15 de julio de 1981 .

\section{9. «ADDENDA» DE ALCANCE}

Redactadas definitivamente y entregadas las páginas precedentes, el $B O E$ de 18 de mayo de 1982 publicó ocho sentencias del Tribunal Constitucional, de las cuales siete resolvían otros tantos recursos de amparo y, salvo una (sobre el art. 30.2 Const., objeción de conciencia: por cierto, estimatoria del recurso), eran precisamente contra decisiones de órganos judiciales: dos civiles, dos penales y dos laborales (una de éstas, estimatoria).

Artículos de la Constitución invocados en dichos seis recursos: el 14, en dos casos; el 24, en cinco, y el 28, en uno.

Para el tema abordado en este trabajo es oportuno sintetizar la doctrina que el Tribunal Constitucional sienta en las aludidas resoluciones acerca de tres puntos: 
a) Sobre la invocación del derecho vulnerado en un caso penal: el trámite oportuno para hacerlo no es el escrito de apelación, sino la vista oral, aunque desde luego debe probar el recurrente, cosa que no ha hecho en este caso, que realizó tal invocación, por lo que se deniega el amparo solicitado: sentencia de 30 de abril de 1982.

b) Recursos utilizables en la vía judicial: hay que entender esa exigencia en términos de razonable defensa, como ya estableció la sentencia de 30 de marzo de 1981 ( $B O E$ de 14 de abril) y, equivocado o no, lo cierto es que el interesado recurrió en casación, sobre cuya procedencia se pronunciará luego el Tribunal, y el plazo para poder interponer el recurso de amparo comienza precisamente a partir de la notificación de la última resolución judicial (aquí, el auto del TS que rechazó la queja por inadmisión del recurso de casación): sentencia de 21 de abril de 1982 .

c) Si las dos declaraciones anteriores se limitan a ratificar la línea mantenida ya anteriormente por el TC, no ocurre lo mismo con el punto relativo al cómputo del plazo de veinte días para interponer el recurso de amparo: frente a lo resuelto en los dos autos citados en la nota 34 y última, las sentencias de 21 de abril y 12 de mayo de 1982 establecen (como en dicha nota se postuló y postula) que en el cuestionado cómputo no entran los días inhábiles, pues frente al art. 5.2 CC (cómputo civil de los plazos) prevalecen en nuestro caso los arts. 80 LOTC y 303 y 305 de la Ley de Enjuiciamiento Civil (días hábiles). Es de prever y de desear que se consolide esta nueva jurisprudencia. 